\title{
Assessing the Contamination of Food and the Environment With Taenia and Echinococcus Eggs and Their Zoonotic Transmission
}

\author{
Cristian A. Alvarez Rojas ${ }^{1} \cdot$ Alexander Mathis $^{1} \cdot$ Peter Deplazes $^{1}$
}

Published online: 10 April 2018

(C) The Author(s) 2018

\begin{abstract}
Purpose of Review Cystic and alveolar echinococcosis, caused by Echinococcus granulosus sensu lato and E. multilocularis, respectively, and Taenia solium cysticercosis are serious but neglected zoonotic diseases, caused by extra-intestinal cestode (tapeworm) infections. Humans are dead-end hosts for Echinococcus spp and acquire the infections by uptake of parasite eggs, either with contaminated food or via exposure by hand-mouth contact to eggs derived from the contaminated environment, including skin or coat of definitive hosts. Data related with the production of eggs of these parasites, their survival in the environment and the methodology for detection in food and environmental samples are summarized.

Recent Findings The detection of taeniid DNA, more specifically from E. multilocularis, in food and soil has recently been described in some European countries. These findings have been directly connected with an increase in prevalence of human infections in countries like Poland.

Summary The isolation and molecular identification of taeniid eggs is technically challenging and little standardized. The detection of taeniid DNA per se does not imply viability of eggs, and this must be considered when interpreting molecular results for transmission risk. Finally, easy, affordable, and sensitive methods replacing animal experiments should be developed to assess the viability of taeniid eggs isolated from environmental and food/water sources.
\end{abstract}

Keywords Echinococcus granulosus $\cdot$ Echinococcus multilocularis $\cdot$ Taenia solium $\cdot$ Taeniid $\cdot$ Oncosphere $\cdot$ Viability $\cdot$ Detection

\section{Introduction}

Foodborne and soil-transmitted parasitic zoonoses are important but neglected human diseases [1]. Although most of them have a worldwide distribution, there is agreement that their burden is highly focal, resulting in significant morbidity and mortality among vulnerable populations [2]. A diverse range of parasites is responsible for these infections, including protozoa, nematodes, trematodes, and cestodes. The cestode group includes the most important zoonotic helminths, Echinococcus granulosus sensu lato (s.1.) and E. multilocularis, responsible for cystic and alveolar echinococcosis (CE and $\mathrm{AE}$ ), respectively. Both diseases are characterized by extra-intestinal development of larval (metacestode) parasite stages. High

This article is part of the Topical Collection on Foodborne Pathogens

Peter Deplazes

deplazesp@access.uzh.ch

1 Institute of Parasitology, Vetsuisse Faculty, University of Zürich, Winterthurerstr. 266a, 8057 Zürich, Switzerland endemic areas of $\mathrm{CE}$ exist on all continents, whereas the highest disease burden of $\mathrm{AE}$ is in Asia, but increasing infection rates have been reported in some areas of Europe [3, 4]. Latest estimates suggest an annual global incidence of at least 188,000 new CE cases and 18,235 new AE cases (91\% occurring in China) per year [2,5]. The global burden of the diseases were calculated as 285,407 DALYs (disability adjusted life years) for CE without adjusting for underreporting and more than 1 million DALYs when underreporting is taken into consideration [6]. For AE, a median of 666,434 DALYs was estimated [5]. CE has a mortality rate between 1 and $2 \%$, while mortality is much higher in the case of AE, with significant regional differences: $2-5 \%$ in Western and Central Europe and North America, 10-30\% in Eastern Europe, and 100\% mortality elsewhere [2]. Furthermore, tapeworm infections with Taenia saginata, T. asiatica, and T. solium (taeniosis) in humans cause mild intestinal disorders after ingestion of the larval stages (cysticerci) in meat. In addition, eggs of T. solium and in rare cases also of other Taenia spp. such as T. crassiceps, T. martis, or T. multiceps [7] can also invade humans which serve as dead-end hosts, causing (neuro-)cysticercosis [8]. 
T. solium cysticercosis causes high morbidity and lethality in endemic areas of America, Africa, and Asia [8]. CE and AE as well as cysticercosis develop after uptake of embryonated worm eggs from food or the environment. However, based on the available data, quantification of the ways of transmission is not possible. Taeniid eggs can be differentiated by morphology to family level only, and molecular tools are available to identify eggs to species or genotype level $[9,10 \bullet, 11]$. Though such studies are important to identify transmission pathways, the methodology needs to be critically assessed.

\section{Intestinal Reproduction and Transmission Biology of Taeniids}

The taeniid life cycles involve an intermediate host, in which the larval stages develop extra-intestinally, and a definitive host harboring the intestinal tapeworms (see Table 1 for characteristics of taeniid life cycles). The development of the intestinal stages can be divided into proglottisation, i.e., the sequential formation of new reproductive units (proglottides) and their growth and maturation, yielding gravid proglottides containing hundreds (Echinococcus spp.) or thousands of eggs in the uteri (Taenia spp.). The relative small reproduction rate of Echinococcus spp. per worm (few $\mathrm{mm}$ in length, $<6$ proglottides) as compared with Taenia spp. (several meters in length, with hundreds of proglottides) is compensated by the worm numbers per host, with up to several 100,000 Echinococcus but usually $<10$ Taenia worms. Taenia spp. are long living parasites with a continuous proglottisation of the individual worms (Table 1). In contrast, the survival dynamics of Echinococcus spp. in the definitive host has to be considered at population level. Quantitative assessment revealed that the main E. multilocularis worm burden (95\%) was eliminated during the first 27 days of patency in foxes and 43 days in dogs. Total egg numbers were comparable in both host species despite much lower worm burdens in dogs [14]. Experimental infections with E. multilocularis from Japanese origin in foxes and dogs confirm this relatively short major patent period [19]. A similar dynamic of egg excretion was determined for E. granulosus with most eggs being excreted within the first month of patency [13]. Thus, proglottisation seems of minor significance for Echinococcus spp., and gravid proglottides are probably predominately excreted with the entire worms. In both these experimental studies, residual worm burdens were detected in most animals 80-90 days after the inoculation [13, 14]. In general, $E$. multilocularis produces fewer eggs per worm than E. granulosus [20]. The average number per gravid proglottis was 178 eggs (range 158 to 210) in naturally infected foxes [21]. However, in an experimental infection, the average number of eggs excreted per worm was 114, 42, and 27 in dogs, raccoon dogs, and foxes, respectively [14]. These lower egg numbers are related to the fact that many worms are eliminated in the first month of patency before reaching gravidity and that immature eggs are dissolved in the carnivore intestine.

Taenia have much higher egg production capacities, with reports of around 55,435 $(15,790-83,400)$ eggs/proglottis for T. hydatigena [22] and 88,000 for T. ovis [23]. On average, $T$. hydatigena produced 2.3-4.9 proglottides per day over an observation time of 41-428 days [22]. Other reports suggested that a person infected with $T$. saginata disseminates per day about half a million eggs [24] and 1-8 proglottides [15]. Egg excretion is not continuous but related to the release of proglottides or entire worms. In an experimental study, dogs

Table 1 Characteristics of the life cycle of major zoonotic Taenia and Echinococcus species

\begin{tabular}{|c|c|c|c|c|c|c|}
\hline Species & Definitive host & Prepatency & Patency & $\begin{array}{l}\text { Egg number } \\
\text { per proglottis }\end{array}$ & Intermediate hosts & $\begin{array}{l}\text { Dead-end } \\
\text { intermediate hosts }^{\mathrm{b}}\end{array}$ \\
\hline $\begin{array}{l}\text { Echinococcus } \\
\text { granulosus sensu lato } \\
\text { all the taxa causing } \\
\text { CE }[3,12]\end{array}$ & $\begin{array}{l}\text { Dog, (fox), dingo, } \\
\text { jackal and hyena } \\
{[12]}\end{array}$ & 34-58 days & $\begin{array}{l}\text { 2-3 months (residual worm } \\
\text { burdens much longer) [13] }\end{array}$ & $100-1500$ & $\begin{array}{l}\text { Sheep, cattle, pigs, } \\
\text { camels, goats, } \\
\text { macropods, } \\
\text { buffaloes [12] }\end{array}$ & $\begin{array}{l}\text { Human, other } \\
\text { mammals not in the } \\
\text { food chain of } \\
\text { definitive host }\end{array}$ \\
\hline E. multilocularis & $\begin{array}{l}\text { Fox, dog, (cat), } \\
\text { wolf, raccoon } \\
\text { dog, coyote, } \\
\text { jackal [12] }\end{array}$ & 26-28 days & $\begin{array}{l}1 \text { month for } 98 \% \text { of the worm } \\
\text { burden, residual worm } \\
\text { burdens several months } \\
\text { longer [14] }\end{array}$ & 300 & $\begin{array}{l}\text { Predominantly voles } \\
\text { (Arvicolinae) [12] }\end{array}$ & $\begin{array}{l}\text { Human, domestic and } \\
\text { wild pig, dog, } \\
\text { monkeys }\end{array}$ \\
\hline Taenia solium & Human & 5-10 weeks & $\begin{array}{l}\text { Less than } 5 \text { years (reviewed in } \\
\text { [8]) }\end{array}$ & 50,000 & Pig, wild boar & $\begin{array}{l}\text { Humans with } \\
\text { cysticercosis }\end{array}$ \\
\hline T. saginata & Human & $\begin{array}{c}86 \text { days } \\
{[15]}\end{array}$ & Few up to 30 years [16] & $50,000-100,000$ & Cattle & $\begin{array}{l}\text { Pigs are susceptible to } \\
\text { experimental } \\
\text { infection [17] }\end{array}$ \\
\hline T. asiatica & Human & $\begin{array}{l}122 \text { days } \\
{[18]}\end{array}$ & Not known & 80,000 & Pig, wild boar & \\
\hline
\end{tabular}

a Total egg numbers; see the "Intestinal reproduction and transmission biology of taeniids" section for more details

${ }^{\mathrm{b}}$ Without epidemiological significance 
infected with $T$. hydatigena excreted $64 \%$ of all proglottides spontaneously (not associated with defecation), and such proglottides harbored on average 14,820 eggs [22]. During a voluntary self-infection with $T$. saginata, "involuntary proglottides discharge throughout the infection period" was observed [15].

\section{Ways of Taeniid Egg Transmission and Infection Risks for Humans}

Humans acquire the infection by per oral uptake of infective eggs, but the exact ways of transmission are not well understood and cannot be quantified. They might vary within the endemic areas, e.g., in rural and urban environments, and might be very distinct in larger endemic areas based on sociocultural and economic reasons. Transmission could partially be linked to a typical foodborne way after ingestion of viable eggs contaminating unwashed vegetables/fruits/berries. Hand-to-mouth is another putative way of transmission, after contact with taeniid eggs in the environment. A recently published meta-analysis reported an average hand-to-mouth frequency in children ranging from 6.7 to 28.0 contacts/h in indoor situations and 2.9 to 14.5 contacts/h outdoors [25].

Taeniid eggs are dispersed from the carnivore feces with water or adhering to objects (e.g., hoofs of sheep, shoes, and tires). Birds and flies have been speculated to be possible vectors [26]. Taeniid eggs can adhere to the coat of infected dogs or foxes, and thus, there is an obvious risk originating from direct contacts with definitive hosts. Furthermore, dogs rolling in feces can be externally contaminated without being infected. Investigations with five dogs infected with T. hydatigena revealed $173-210 \mathrm{eggs} / \mathrm{cm}^{2}$ in the peri-anal region and 4-20 eggs $/ \mathrm{cm}^{2}$ on other body areas, including even $13 \mathrm{eggs} / \mathrm{cm}^{2}$ on the nose [22]. A gravid proglottis of $E$. multilocularis has been found in the peri-anal region of a naturally infected dog [27], and examination of hair coat of 46 foxes revealed taeniid eggs in 11 animals (three cases confirmed to be E. multilocularis) [28]. Older data document the presence of E. granulosus eggs in dogs' coat. Single eggs were found in the muzzle and paws of experimentally infected dogs [29], and taeniid eggs were detected in the anal region, around the mouth and on the coat of rural dogs from Nigeria infected with E. granulosus (confirmed at necropsy) [30]. These data confirm the potential infection risk by close contact with dogs or foxes (e.g., for hunters).

Differences in the environmental dispersal of eggs of E. multilocularis and E. granulosus s.l. should be considered. Eggs of E. granulosus are often localized in the dog/livestock/ human environment. In fact, feeding dogs with raw livestock viscera perpetuates transmission in a variety of endemic settings [31]. For example, a restricted local transmission on small farm level with home production of pork and vegetables has been described for E. intermedius (G7) in Lithuania [32]. E. multilocularis predominantly occurs in a wild animal cycle, with a high dispersal of eggs in the environment strongly linked to the fox defecation behavior (marking of home ranges and feeding places) [33]. Recent investigations in Central Europe have shown that the increase in fox populations affected the dispersal of eggs in rural and urban areas [27, 34, 35]. Similar trends of the urbanization of the E. multilocularis cycle have been observed in Canada (coyotes invading cities) and in Asia (stray dogs) [27, 36]. Even though prevalences in dogs may be low in Central Europe (e.g., 0.3-3\%), they can constitute a relevant zoonotic risk [37].

A recent systematic literature review [38•] identified the following definitive host related risk factors for human AE: dog ownership or playing with dogs; vocational factors like being a farmer or handling foxes. However, the limitations of such studies are the rather small numbers of patients diagnosed after long incubation periods (up to 10 years) and the difficulty to specify certain factors that represent more a general lifestyle than the particular risk factor requested. Dog ownership and contact with dogs are key risk factors for human $\mathrm{CE}$ in rural endemic areas, together with the presence of free-roaming owned, community-owned and/or stray dogs in urban or peri-urban areas [31].

The extra-intestinal larval stage of T. solium can be acquired by humans as a truly foodborne infection, after ingestion of viable eggs present on vegetables irrigated with sewage containing human feces or on food manipulated by a person with a patent intestinal infection. In an outbreak of neurocysticercosis in an orthodox Jewish community in New York, domestic servants originating from an endemic area were identified as the most probable source of infection [39]. Risk factors associated with seropositivity in humans from old studies in Mexico included "history of passing tapeworm proglottis," "frequent consumption of pork," and "poor personal and household hygiene" [40]. Transmission of T. saginata independently from defecation has been evidenced by observations of very high infections in calves associated with an infected person handling the animals [41].

\section{Tenacity of Taeniid Eggs}

Detailed knowledge on the physical resistance of taeniid eggs is relevant when assessing their inactivation in food, e.g., by thermal treatment. Earlier reports showed that Echinococcus eggs remain viable at temperatures below zero for long periods of time, but only temperatures of -70 to $-80{ }^{\circ} \mathrm{C}$ for 96 and $48 \mathrm{~h}$, respectively, inactivate the eggs (reviewed in [42]). On the other hand, eggs survived temperatures of $+65^{\circ} \mathrm{C}$ for $2 \mathrm{~h}$ but were killed after $3 \mathrm{~h}\left[43^{\bullet}\right.$. Eggs were more resistant to elevated temperatures if suspended in water as compared to an exposure at $70 \%$ relative humidity [ $\left.43{ }^{\bullet}\right]$. This is relevant since 
eggs can be in water droplets on vegetables. T. saginata oncospheres could artificially be activated after maintaining them for 335 days at $4{ }^{\circ} \mathrm{C}$ but not after 60 days at room temperature $\left(20^{\circ} \mathrm{C}\right)$ (Silverman, 1956 reviewed in [44]). In the natural environment, taeniid eggs can remain viable for long periods of time. A maximal survival time of $E$. multilocularis eggs of 240 days under German autumn/ winter conditions and 78 days in summer was reported [45]. Eggs of E. granulosus remained viable up to 41 months in the environment of the Argentinian Patagonia [46] and for only four winter months in New Zealand [47]. For Taenia eggs, fewer studies on viability in the environment have been conducted; old studies reported infection in cattle after inoculation of $T$. saginata eggs maintained for 23 weeks under winter and spring conditions in Denmark (Jepson and Roth, 1949 reviewed in [44]), and a small proportion of eggs remained infective after exposure to natural conditions in Denmark for 6.5-8.5 months depending on seasonal variation [48].

\section{Detection of Taeniid Eggs}

\section{Diagnosis of Intestinal Taeniid Infections by Fecal Examination}

The diagnostic approaches for detection of intestinal infections in fecal specimens of definitive hosts have extensively been reviewed for Echinococcus $[9,49]$ and for human Taenia infections [50]. Eggs of taeniid parasites can efficiently be enriched from diagnostic specimens [51] but are indistinguishable by morphology (Fig. 1). Molecular techniques allow their identification to species/genotype level which is particularly relevant to identify the zoonotic species (e.g., [10, 34, $52-55 \bullet, 56])$. DNA amplification techniques are claimed to detect one single egg, which is convincing as taeniid eggs contain between 18 and 56 cells [57-59]. It was estimated that a single taeniid egg (T. hydatigena) contains around 7000 mitochondrial targets, and the detection limit of PCRs targeting the mitochondrial DNA was estimated at 33 copies [10•]. In our lab, a reliable method combining sieving (eggs retained in a $20-\mu \mathrm{m}$ sieve), microscopy, multiplex PCR on DNA from taeniid-positive samples (egg-DNA PCR) and optionally confirmatory sequencing was developed $[10 \bullet, 51]$ aiming to differentiate eggs of E. granulosus s.1., E. multilocularis and other taeniids, and the method has extensively been used for individual diagnosis (e.g., [54, 60, 61]) and in studies investigating field-collected specimens (see below). However, molecular analyses of taeniid eggs can also be performed after isolation with classical diagnostic sedimentation/flotation procedures $[62,63]$. DNA amplification on DNA acquired directly from specimens, i.e., omitting the egg isolation step (copro-DNA PCR), has been shown to be successful in fresh specimens [55•, 64-66]. For example, classical PCR on fecal droppings of foxes experimentally infected with E. multilocularis was highly sensitive with samples from the high- and low-patent period and also detected around $20 \%$ of the samples from the prepatent period [64]. Differences in analytical sensitivity for $E$. multilocularis were described when using different DNA isolation kits and different PCR approaches [67]. Tests to detect parasite antigens by ELISA (coproantigen-ELISA) usually are genus-specific, having good sensitivities in animals with high worm burden $[9,49]$. Such tests are highly useful in environmental studies involving large numbers of samples (see below).

\section{Determination of Environmental Contamination}

The investigation of fecal samples collected in the environment allows a partial estimate of the parasite contamination in the field. In the case of $E$. multilocularis, it has been proposed to express it as a "contamination index," basically because it is not possible to know if multiple samples originated from one or several individuals [9]. The identification of the animal species of the feces can be done by examination of size, shape, smell, and contents, but molecular tools allow specific host identification [56, 68]. Copro-ELISA has been applied to understand temporal aspects of urban transmission of $E$. multilocularis in Switzerland. The method was validated by confirmation of the results with egg-DNA PCR [34] and was used to assess the environmental contamination in France [69] or during fox baiting studies with praziquantel (reviewed in [37]). Egg-DNA PCRs with DNA from fecal samples from the environment followed by genetic analyses have been used in several epidemiological studies [68, 70-72]. Copro-DNA PCRs with such specimens were applied in a few studies using real-time PCRs $[56,66,68]$. As "free" DNA in these samples is increasingly degraded with time, real-time PCR targeting short stretches of DNA are mandatory; confirmation of results by sequencing the very short amplicons, however, is not straightforward. Therefore, a confirmatory PCR yielding a longer fragment was recently suggested [68].

A number of studies have been performed to detect taeniid eggs in non-fecal related, environmental samples. Taeniid eggs were microscopically detected in 9/482 flotations assays of water samples after an outbreak of $T$. saginata in Canada [73]. In the same study, the authors also described the low egg recovery from spiked water samples. Taeniid eggs have also been detected in raw wastewater using a centrifugation/ flotation and biphasic separation protocol [74]. Earlier research $[75,76]$ done in $T$. solium endemic areas failed to detect taeniid eggs in soil samples (e.g., areas used for open-air defecation) and water samples (river). Taeniid eggs isolated from soil and water samples were identified as E. granulosus by using a monoclonal antibody on the oncospheres released from the eggs [52]. This approach was not further used. 

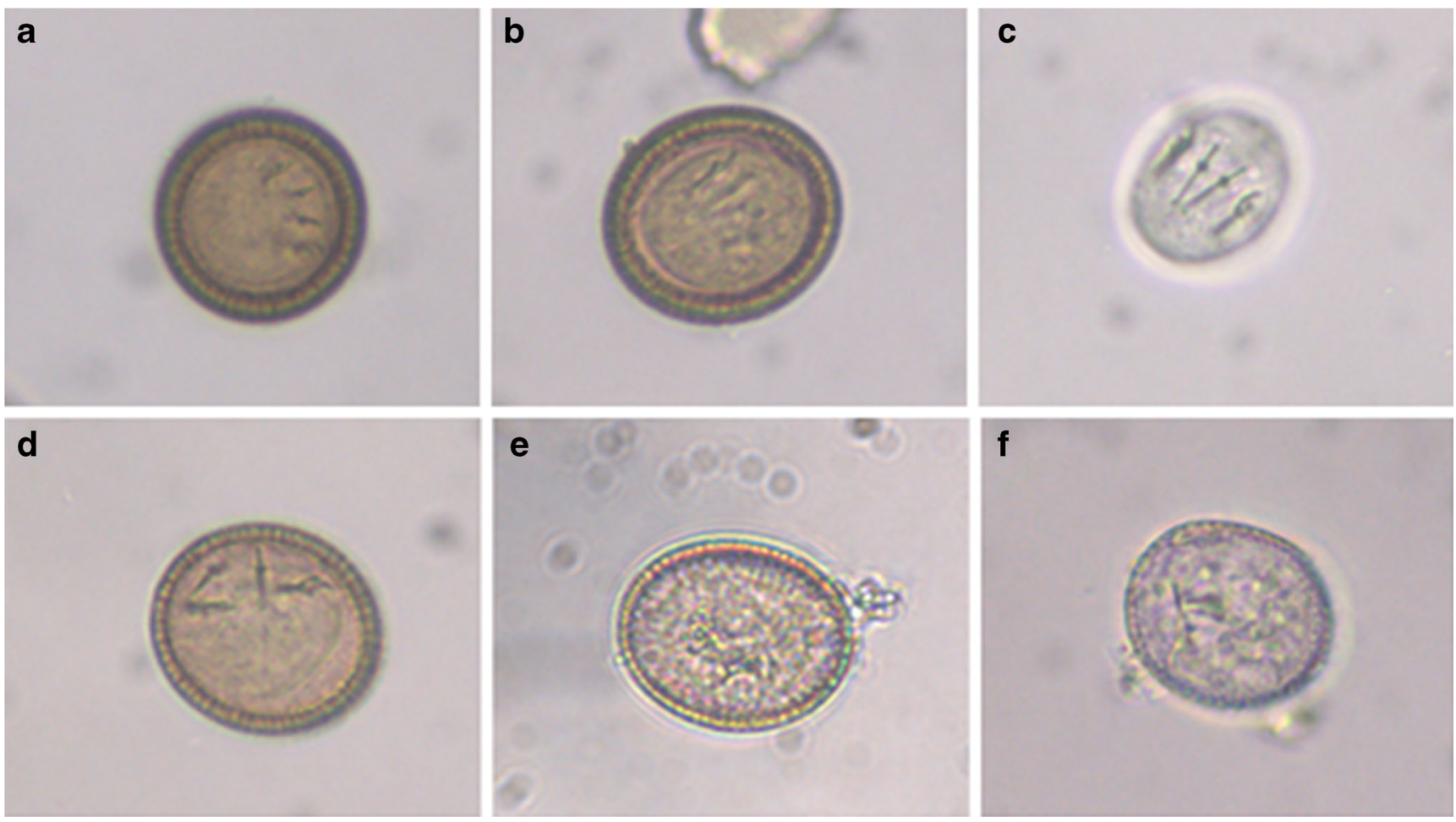

Fig. 1 In general, taeniid eggs are typically spherical to ellipsoid in shape, ranging in size from 30 to $50 \mu \mathrm{m}$ and from 22 to $44 \mu \mathrm{m}$ in their two diameters. All eggs in this figure were isolated from Echinococcus multilocularis and illustrate the typical features of a taeniid egg. a, b Mature eggs showing a thick embryophore, clearly visible oncosphere and pairs of hooks in parallel alignment; these microscopic features suggest these are viable eggs. c Oncosphere released from a viable egg after treatment with $2 \%$ sodium hypochlorite for $2 \mathrm{~min}$. d Non-viable egg stored for 2 years at $4{ }^{\circ} \mathrm{C}$ in physiological saline solution showing unparalleled hooks. e, f Immature eggs showing a thin embryophore and no oncosphere; e was stored for 8 months in saline solution at $4{ }^{\circ} \mathrm{C}$ and $\mathbf{f}$ was freshly removed from an adult specimen of $E$. multilocularis infecting a fox
Recently, genetic tests were applied. Microscopic analyses of 120 soil samples from gardens of rural homestead in a highly E. granulosus endemic area in Kazakhstan revealed the presence of eggs of Toxocara spp., Toxascaris leonina, Trichuris spp. and taeniid eggs in several specimens. Egg-DNA PCR revealed E. granulosus in 5/21 taeniid egg positive samples [77]. In a study in Poland, 62 soil samples were collected, but no sampling strategy is given (random, grids) [78]. Eggs were concentrated as for microscopic examination, and taeniid eggs were identified in a subsample (8/37). Seven samples were PCR-positive for E. multilocularis, of which three were collected near fox dens. A major drawback of this work is the use of a classical, nested PCR which is highly prone to cross-contamination, particularly as E. multilocularis DNA was used as positive reaction control. More recently, the egg-DNA PCR approach was applied to investigate the presence of E. multilocularis (and Toxocara) in soil under and close to fox fecal samples [35]. Three soil samples collected under 25 E. multilocularis positive fecal samples were positive, but this was not a statistically significant difference compared to the results of the soil samples collected under/near the negative fecal samples. This illustrates that determining parasite contamination with environmental soil specimens is much less efficient than with feces. So far, there are no attempts to identify taeniids by PCR with DNA directly isolated from soil (soil-DNA PCR), and this seems to be a hopeless task due to the patchy distribution of eggs, the degradation of free DNA and the presence of PCR-inhibitory substances in soil.

\section{Determination of Food Contamination}

The scientific literature provides several reports on microscopic findings of taeniid eggs in vegetables, mainly in Asia and Africa, with contamination rates ranging between 0.9 and $18.3 \%$ (Table 2). Presently, there is no standardized methodology for the detection of taeniid eggs in food samples. We are aware of two studies using egg-DNA PCR to assess food contamination with E. multilocularis. In a first study [91], 103 samples (fruit, vegetable, mushrooms) were subjected to the procedure as mentioned above for soil samples [78], i.e., concentration of eggs as for microscopic examination, but no effort was made to demonstrate the presence of eggs. Cross-contamination-prone nested PCRs as used in their earlier work [78] revealed nearly onefourth positive samples. This publication triggered some discussion in the literature, particularly questioning the finding of positive raspberries collected from the bushes at some distance 
Table 2 Studies documenting microscopic detection of taeniid and other parasite stages in vegetables and fruits

\begin{tabular}{|c|c|c|c|c|c|c|}
\hline Country & $\begin{array}{l}\text { Number of food } \\
\text { samples }\end{array}$ & $\begin{array}{l}\text { Samples with parasites } \\
\text { detected }(\%)\end{array}$ & $\begin{array}{l}\text { Weight of } \\
\text { sample }\end{array}$ & $\begin{array}{l}\text { Samples with taeniid } \\
\text { eggs }(\%)\end{array}$ & Other parasites & Reference \\
\hline Iran & 772 & $14.8 \%$ & $200-300 \mathrm{~g}$ & $0.9 \%$ & $\begin{array}{l}\text { Ascaris lumbricoides }(3.3 \%), \\
\text { Trichuris trichiura }(2.2 \%), \\
\text { hookworms }(2.9 \%), \\
\text { Toxocara spp. }(1.6 \%), \\
\text { Trichostrongylus spp. }(1.5 \%) \\
\text { and Hymenolepis nana }(2.2 \%)\end{array}$ & [79] \\
\hline Iran & 304 & $\begin{array}{l}32.6 \% \text { unwashed } \\
1.3 \% \text { traditionally washed }\end{array}$ & $200 \mathrm{~g}$ & $9.2 \%$ unwashed & $\begin{array}{l}\text { A. lumbricoides }(14.1 \%) \text {, } \\
\text { Toxocara } \text { spp. }(3.3 \%), \\
\text { Trichostrongylus } \text { spp. }(4.3 \%) \text {, } \\
\text { Giardia spp. }(8.2 \%) \\
\text { Entamoeba coli }(9.2 \%)\end{array}$ & {$[80]$} \\
\hline Iran & $\begin{array}{l}453 \text { unwashed } \\
448 \text { washed }\end{array}$ & $25.2 \%$ unwashed & $250 \mathrm{~g}$ & $4.8 \%$ unwashed & $\begin{array}{l}\text { A. lumbricoides }(8.1 \%) \text {, } \\
\text { Cryptosporidium spp. }(2.8 \%) \text {, } \\
\text { Enterobius vermicularis } \\
(2.6 \%), \text { Strongyloides } \mathrm{spp} . \\
(1.1 \%), \text { Toxocara } \mathrm{spp} .(3.9 \%) \text {, } \\
\text { and Entamoeba coli }(2.4 \%)\end{array}$ & {$[81]$} \\
\hline Iran & $\begin{array}{l}218 \text { unwashed } \\
436 \text { washed }\end{array}$ & $\begin{array}{l}9.6 \% \text { unwashed } \\
0 \text { in washed }\end{array}$ & $200 \mathrm{~g}$ & $1.8 \%$ & $\begin{array}{l}\text { H. nana }(0.4 \%), \text {, trichiura }(0.9 \%) \text {, } \\
\text { A. lumbricoides }(2.2 \%), \\
\text { Tricostrongylus } \text { spp. }(2.7 \%), \\
\text { Dicrocoelium } \text { spp. }(33.5 \%)\end{array}$ & {$[82]$} \\
\hline Jordan & 133 & $29 \%$ & $250 \mathrm{~g}$ & $6 \%$ & $\begin{array}{l}\text { Ascaris } 28(21.1 \%), \text { Toxocara } \\
\quad(7.5 \%), \text { Giardia }(6.8 \%), \\
\text { Fasciola }(4.5 \%), \\
\text { Entamoeba histolytica }(3.8 \%)\end{array}$ & [83] \\
\hline Libya & 126 & $58 \%$ & $100 \mathrm{~g}$ & $22 \%$ & $\begin{array}{l}\text { Ascaris }(68 \%), \text { Toxocara cati } \\
\quad(26 \%), \text { Toxocara canis }(18 \%), \\
\text { Giardia }(10 \%)\end{array}$ & {$[84]$} \\
\hline Nigeria & 960 & $8.4 \%$ & $250 \mathrm{~g}$ & $1.2 \%$ & $\begin{array}{l}\text { A. lumbricoides }(4.5 \%) \text {, } \\
\text { T. trichiura }(3.9 \%) \text {, hookworms } \\
(1.5 \%) \text {, Strongyloides stercoralis } \\
(0.7 \%), \text { E. vermicularis }(0.4 \%) \\
\text { and H. nana }(0.42 \%)\end{array}$ & {$[85]$} \\
\hline Nigeria & 1130 & $3.5 \%$ & $200 \mathrm{~g}$ & $0.5 \%$ & $\begin{array}{l}\text { Ascaris }(0.5 \%) \text {, hookworm }(1.2 \%) \text {, } \\
\text { Trichuris }(0.5 \%) \\
\text { S. stercoralis }(0.6 \%)\end{array}$ & {$[86]$} \\
\hline Nigeria & 199 & $57.8 \%$ & $250 \mathrm{~g}$ & $18.3 \%$ & $\begin{array}{l}\text { Toxocara spp. (48.3\%), } \\
\text { Strongyloides spp. }(19.2 \%), \\
\text { Ancylostoma } \text { spp. }(10 \%), \\
\text { Trichuris spp. }(3.3 \%) \text { and } \\
\text { Enterobius } \text { spp. }(0.8 \%)\end{array}$ & [87] \\
\hline Nigeria & 120 & $68.3 \%$ & Unknown & $4.2 \%$ & $\begin{array}{l}\text { A. lumbricoides }(16.7 \%) \text {, } \\
\text { hookworm }(18.3 \%) \text {, } \\
\text { S. stercoralis }(45.8 \%) \text {, } \\
\text { B. coli }(0.8 \%)\end{array}$ & {$[88]$} \\
\hline Turkey & $\begin{array}{l}203 \text { unwashed } \\
406 \text { washed }\end{array}$ & $\begin{array}{l}5.9 \% \text { unwashed } \\
0 \text { in washed }\end{array}$ & $200 \mathrm{~g}$ & $3.5 \%$ & $\begin{array}{l}\text { Toxocara spp. }(1.5 \%) \text { and } \\
\text { A. lumbricoides }(1 \%)\end{array}$ & [89] \\
\hline Turkey & 111 & $6.3 \%$ & $100 \mathrm{~g}$ & $2.7 \%$ & $\begin{array}{l}\text { Toxocara }(2.7 \%) \text {, A. lumbricoides } \\
(1.8 \%) \text { and } \\
\text { E. vermicularis }(0.9 \%)\end{array}$ & [90] \\
\hline
\end{tabular}

from the ground [92], though such a contamination cannot be excluded as flies were shown to transmit such eggs [26]. A second investigation on the presence of cestode eggs in feed (vegetables, fruits) [60] was triggered by frequent cases of alveolar echinococcosis in primates kept in captivity at a Zoo. EggDNA PCR using multiplex PCR/sequencing [10•] on filtered samples revealed non-zoonotic Taenia spp. of dogs, foxes, or cats in 14 of the total 95 samples (each consisting of the washing of around 40 heads of lettuce enriched with a day ration of fruits and vegetables) originating from Switzerland. Taeniid-DNA was further detected in 13 (28\%) of 46 samples of vegetables originating from different parts of Europe (vegetables and fruits as 
mentioned above), including E. granulosus s.l. (2), T. crassiceps (1), T. hydatigena (2), T. multiceps/serialis (2), T. saginata (1) and T. taeniaeformis (5). Although DNA of E. multilocularis was not identified in this study, the detection of DNA of other taeniids of foxes reveals that feed potentially pose a source for E. multilocularis eggs. So far, methods used to estimate the environmental or food contamination with taeniid eggs/DNA are not allowing to assess their viability, and hence, the results of such studies have to be carefully interpreted, especially considering that parasite DNA (e.g., Trichuris) [93] and also taeniid eggs [94] can be detected in archeological samples.

\section{Determination of the Viability of Taeniid Eggs}

Taeniid eggs develop to the embryonated stage within the proglottis, a further maturation of taeniid eggs in the environment has to our knowledge not convincingly been documented. Experimental studies with taeniid eggs collected from the last proglottides of gravid worms showed that only a variable proportion of these eggs are mature and viable. Experimental inoculations with taeniid eggs obtained from gravid proglottides revealed usually low $(<2.5 \%)$ development rates into larval stages in suitable hosts (for E. granulosus infections [95, 96], for Taenia spp. [97-99]).

A qualitative estimation of the viability of taeniid eggs collected from worms or isolated from feces can be achieved by microscopy by experienced scientists; criteria for viable (mature) eggs are the thick embryophore, the clearly visible oncosphere and the pairs of hooks in parallel alignment (Fig. 1). An elegant technique to assess the viability of taeniid eggs freshly collected from proglottides is their treatment with sodium hypochlorite for a few minutes to dissolve their embryophore. Immature eggs are destroyed by this procedure while viable oncospheres are protected by a resistant membrane [100, 101$]$. Based on this observation, a sodium hypochlorite resistance test (SH-RT) was introduced and compared with the in vitro activation and in vitro development of oncospheres [102]. However, the results of the SH-RT did not correlate with the in vitro activation and development rate of $T$. hydatigena oncospheres after 270 days preservation in water at $+4{ }^{\circ} \mathrm{C}$ or $-28^{\circ} \mathrm{C}$. Furthermore, SH-RT was not reliable to assess the viability of heat-exposed eggs of E. multilocularis [43•] or E. granulosus [103]. Therefore, SH$\mathrm{RT}$ is useful to determine the rate of mature eggs after isolation from gravid worms, and this is needed to standardize infection doses in experimental studies [101]. An in vitro method including treatment with sodium hypochlorite and assessing the permeability of oncospheres to eosin was used to estimate the viability of $E$. granulosus eggs after exposure to different temperatures [103]. This method could be used in the future for tenacity studies; however, no in vivo validation of the method was performed. Another recent study reported the survival of $T$. hydatigena eggs exposed at different conditions of relative humidity using $0.1 \%$ trypan blue to assess viability [104]; similar to other studies, no in vivo confirmation of infectivity of the treated eggs was included. So far, the most reliable viability test for taeniid eggs is the experimental infection in susceptible animals. For example, Veit et al. [45] used peroral inoculations of mice to test egg viability after exposure to several climatic conditions. The sensitivity of peroral inoculation is rather low, e.g., only $50 \%$ of mice inoculated with 100 mature eggs developed an infection. Subcutaneous inoculation was recently described as being more sensitive, as metacestode growth was observed in all animals inoculated with 20 eggs [43•]. Therefore, the differentiation of viable and non-viable eggs in the environment remains as an important issue that needs to be addressed in the future; however, so far, no laboratory method replacing experimental infections of suitable hosts has been developed.

\section{General Recommendations}

A critical view on the strategies and the methodology used for risk assessment based on the identification of eggs from zoonotic taeniids in food, water, and environment is necessary.

- Agreement on a standardized procedure for egg isolation including rigid control measures against cross-contamination.

- Professional validation (in silico, diagnostic samples) of specificity and sensitivity of assays.

- Assessment of the environmental contamination from a systematic collection of samples (host feces, soil samples) is required.

- The detection of DNA per se does not imply viability of eggs, and this must be considered when interpreting molecular results.

- Easy and affordable sensitive methods to assess the viability of taeniid eggs isolated from environmental and food/water sources should be developed to replace animal experiments.

\section{Compliance with Ethical Standards}

Conflict of Interest The authors declare that they have no conflict of interest.

Human and Animal Rights and Informed Consent This article does not contain any studies with human or animal subjects performed by any of the authors.

Open Access This article is distributed under the terms of the Creative Commons Attribution 4.0 International License (http:// creativecommons.org/licenses/by/4.0/), which permits unrestricted use, distribution, and reproduction in any medium, provided you give appropriate credit to the original author(s) and the source, provide a link to the Creative Commons license, and indicate if changes were made. 


\section{References}

Papers of particular interest, published recently, have been highlighted as:

- Of importance

1. Dorny P, Praet N, Deckers N, Gabriel S. Emerging food-borne parasites. Vet Parasitol. 2009;163(3):196-206.

2. Torgerson PR, Devleesschauwer B, Praet N, Speybroeck N, Willingham AL, Kasuga F, et al. World Health Organization estimates of the global and regional disease burden of 11 foodborne parasitic diseases, 2010: a data synthesis. PLoS Med. 2015;12(12):e1001920.

3. Deplazes P, Rinaldi L, Alvarez Rojas CA, Torgerson PR, Harandi MF, Romig $\mathrm{T}$ et al. Chapter six - global distribution of alveolar and cystic echinococcosis. In: Thompson RCA, Deplazes P, Lymbery AJ, editors. Advances in parasitology. Academic press; 2017. p. 315-493.

4. Gottstein B, Stojkovic M, Vuitton DA, Millon L, Marcinkute A, Deplazes P. Threat of alveolar echinococcosis to public health-a challenge for Europe. Trends Parasitol. 2015;31(9):407-12.

5. Torgerson PR, Keller K, Magnotta M, Ragland N. The global burden of alveolar echinococcosis. PLoS Negl Trop Dis. 2010;4(6):e722.

6. Budke C, Deplazes P, Torgerson P. Global socioeconomic impact of cystic echinococcosis. Emerg Infect Dis. 2006;12(2):296-303.

7. Brunet J, Pesson B, Chermette R, Regnard P, Grimm F, Deplazes P, et al. First case of peritoneal cysticercosis in a non-human primate host (Macaca tonkeana) due to Taenia martis. Parasit Vectors. 2014;7(1):422.

8. García HH, Gonzalez AE, Evans CAW, Gilman RH, Peru CWG. Taenia solium cysticercosis. Lancet. 2003;362(9383):547-56.

9. Conraths FJ, Deplazes P. Echinococcus multilocularis: epidemiology, surveillance and state-of-the-art diagnostics from a veterinary public health perspective. Vet Parasitol. 2015;213(3):149-61.

10. Trachsel D, Deplazes P, Mathis A. Identification of taeniid eggs in the faeces from carnivores based on multiplex PCR using targets in mitochondrial DNA. Parasitology. 2007;134(6):911-20. This paper provides a thorough method for the discrimination of taeniid eggs in carnivore faeces

11. Armua-Fernandez MT, Nonaka N, Sakurai T, Nakamura S, Gottstein B, Deplazes P, et al. Development of PCR/dot blot assay for specific detection and differentiation of taeniid cestode eggs in canids. Parasitol Int. 2011;60(1):84-9.

12. Romig T, Deplazes P, Jenkins D, Giraudoux P, Massolo A, Craig PS et al. Chapter five - ecology and life cycle patterns of Echinococcus species. In: Thompson RCA, Deplazes P, Lymbery AJ, editors. Advances in parasitology. Academic Press; 2017. p. 213-314.

13. Heath DD, Lawrence SB. Daily egg-production of dogs infected with Echinococcus granulosus. Archives de la hidatidosis. 1991;30:321-8

14. Kapel CMO, Torgerson PR, Thompson RCA, Deplazes P. Reproductive potential of Echinococcus multilocularis in experimentally infected foxes, dogs, raccoon dogs and cats. Int $\mathrm{J}$ Parasitol. 2006;36(1):79-86.

15. Tembo A, Craig PS. Taenia saginata taeniosis: copro-antigen time-course in a voluntary self-infection. J Helminthol. 2015;89(5):612-9.

16. Pawlowski Z, Schultz MG. Taeniasis and cysticercosis (Taenia saginata). In: Dawes B, editor. Advances in parasitology. Academic Press; 1972. p. 269-343.

17. Fan PC, Chung WC, Lin CY, Pawlowski ZS. Experimental infection with Taenia saginata (Poland strain) in Taiwanese pigs. J Helminthol. 1992;66(3):198-204.
18. Chao D, Wong MM, Fan P-C. Experimental infection in a human subject by a possibly undescribed species of Taenia in Taiwan. J Helminthol. 1988;62(3):235-42.

19. Matsumoto J, Yagi K. Experimental studies on Echinococcus multilocularis in Japan, focusing on biohazardous stages of the parasite. Exp Parasitol. 2008;119(4):534-41.

20. Thompson RCA. Chapter two-biology and systematics of Echinococcus. In: Thompson RCA, Deplazes P, Lymbery AJ, editors. Advances in parasitology. Academic Press; 2017. p. 65-109.

21. Thompson RCA, Eckert J. The production of eggs by Echinococcus multilocularis in the laboratory following in vivo and in vitro development. Z Parasitenkd. 1982;68(2):227-34.

22. Deplazes P, Eckert J. The infection of dogs with Taenia hydatigena. Schweiz Arch Tierheilkd. 1988;128:307-20.

23. Gregory GG. Fecundity and proglottid release of Taenia ovis and Taenia hydatigena. Aust Vet J. 1976;52(6):277-9.

24. Pawlowski ZS. Epidemiology and prevention of Taenia saginata infection. In: Flisser A, editor. Cysticercosis: present state of knowledge and perspectives. New York: Academic Press; 1982. p. 69-85.

25. Xue J, Zartarian V, Moya J, Freeman N, Beamer P, Black K, et al. A meta-analysis of children's hand-to-mouth frequency data for estimating nondietary ingestion exposure. Risk Anal. 2007;27(2):411-20.

26. Lawson JR, Gemmell MA. Transmission of taeniid tapeworm eggs via blowflies to intermediate hosts. Parasitology. 1990;100(1):143-6.

27. Deplazes P, Hegglin D, Gloor S, Romig T. Wilderness in the city: the urbanization of Echinococcus multilocularis. Trends Parasitol. 2004;20(2):77-84.

28. Nagy A, Ziadinov I, Schweiger A, Schnyder M, Deplazes P. Hair coat contamination with zoonotic helminth eggs of farm and pet dogs and foxes. Berl Munch Tierarztl Wochenschr. 2011;124(11-12):503-11.

29. Matoff K, Kolev G. The role of the hairs, muzzle and paws of echinococcic dogs in the epidemiology of echinococcosis. Z Tropenmed Parasitol. 1964;15(4):452-60.

30. Okolo MI. Prevalence and public health implications of Echinococcus granulosus in rural dogs in Eastern Nigeria. Int $\mathrm{J}$ Zoonoses. 1986;13(1):19-24.

31. Craig PS, Hegglin D, Lightowlers MW, Torgerson PR, Wang Q. Chapter two-echinococcosis: control and prevention. In: Thompson RCA, Deplazes P, Lymbery AJ, editors. Advances in parasitology. Academic Press; 2017. p. 55-158.

32. Bružinskaite R, Šarkūnas M, Torgerson PR, Mathis A, Deplazes P. Echinococcosis in pigs and intestinal infection with Echinococcus spp. in dogs in southwestern Lithuania. Vet Parasitol. 2009;160(3):237-41.

33. Hegglin D, Bontadina F, Contesse P, Gloor S, Deplazes P. Plasticity of predation behaviour as a putative driving force for parasite life-cycle dynamics: the case of urban foxes and Echinococcus multilocularis tapeworm. Funct Ecol. 2007;21(3):552-60.

34. Stieger C, Hegglin D, Schwarzenbach G, Mathis A, Deplazes P. Spatial and temporal aspects of urban transmission of Echinococcus multilocularis. Parasitology. 2002;124(6):631-40.

35. Umhang G, Bastien M, Renault C, Faisse M, Caillot C, Boucher $\mathrm{JM}$, et al. A flotation/sieving method to detect Echinococcus multilocularis and Toxocara spp. eggs in soil by real-time PCR. Parasite. 2017;24:28.

36. Liccioli S, Giraudoux P, Deplazes P, Massolo A. Wilderness in the 'city' revisited: different urbes shape transmission of Echinococcus multilocularis by altering predator and prey communities. Trends Parasitol. 2015;31(7):297-305. 
37. Hegglin D, Deplazes P. Control of Echinococcus multilocularis: strategies, feasibility and cost-benefit analyses. Int J Parasitol. 2013;43(5):327-37.

38. Conraths FJ, Probst C, Possenti A, Boufana B, Saulle R, La Torre G, et al. Potential risk factors associated with human alveolar echinococcosis: systematic review and meta-analysis. PLoS Negl Trop Dis. 2017;11(7):e0005801. This is a comprehensive risk analysis including the significance of food as source of infection

39. Schantz PM, Moore AC, Muñoz JL, Hartman BJ, Schaefer JA, Aron AM, et al. Neurocysticercosis in an Orthodox Jewish community in New York City. N Engl J Med. 1992;327(10):692-5.

40. Sarti E, Schantz PM, Plancarte A, Wilson M, Gutierrez IO, Lopez AS, et al. Prevalence and risk factors for Taenia solium taeniasis and cysticercosis in humans and pigs in a village in Morelos, Mexico. Am J Trop Med Hyg. 1992;46(6):677-85.

41. Khadaiberganun I. The transmission of Taenia saginata ova to calves via the hands of farm workers. BjullVsesoju. 1980;7:87-90.

42. Eckert J, Gemmell MA, Meslin FX, Pawlowski ZS. WHO/OIE Manual on echinococcosis in humans and animals: a public health problem of global concern World Organisation for Animal Health (Office International des Epizooties) and World Health Organization,2001.

43. Federer K, Armua-Fernandez MT, Hoby S, Wenker C, Deplazes P. In vivo viability of Echinococcus multilocularis eggs in a rodent model after different thermo-treatments. Exp Parasitol. 2015;154:14-9. This investigation is the most recent attempt to assess the viability of sodium hypochlorite resistant oncospheres and their infectivity in a new mouse model

44. Gemmell MA. Safe handling of infected definitive hosts and eggs of Echinococcus spp. Bull World Health Organ. 1968;39(1):122-5.

45. Veit P, Bilger B, Schad V, Schafer J, Frank W, Lucius R. Influence of environmental factors on the infectivity of Echinococcus multilocularis eggs. Parasitology. 1995;110(1):79-86.

46. Sanchez Thevenet P, Jensen O, Drut R, Cerrone G, Grenóvero M, Alvarez H, et al. Viability and infectiousness of eggs of Echinococcus granulosus aged under natural conditions of inferior arid climate. Vet Parasitol. 2005;133(1):71-7.

47. Sweatman GK, Williams RJ. Survival of Echinococcus granulosus and Taenia hydatigena eggs in two extreme climatic regions of New Zealand. Res Vet Sci. 1963;4(2):199-216.

48. Ilsoe B, Kyvsgaard NC, Nansen P, Henriksen SA. A study on the survival of Taenia saginata eggs on soil in Denmark. Acta Vet Scand. 1990;31(2):153-8.

49. Craig P, Mastin A, van Kesteren F, Boufana B. Echinococcus granulosus: epidemiology and state-of-the-art of diagnostics in animals. Vet Parasitol. 2015;213(3):132-48.

50. Gómez-Morales MA, Gárate T, Blocher J, Devleesschauwer B, Smit GSA, Schmidt V, et al. Present status of laboratory diagnosis of human taeniosis/cysticercosis in Europe. Eur J Clin Microbiol Infect Dis. 2017;36:2029-40.

51. Mathis A, Deplazes P, Eckert J. An improved test system for PCRbased specific detection of Echinococcus multilocularis eggs. J Helminthol. 1996;70(3):219-22.

52. Craig PS, Macpherson CN, Watson-Jones DL, Nelson GS. Immunodetection of Echinococcus eggs from naturally infected dogs and from environmental contamination sites in settlements in Turkana, Kenya. Trans R Soc Trop Med Hyg. 1988;82(2):268-74.

53. Sako Y, Nkouawa A, Yanagida T, Ito A. Loop-mediated isothermal amplification method for a differential identification of human Taenia tapeworms. In: Kolpashchikov DM, Gerasimova YV, editors. Nucleic acid detection: methods and protocols. Totowa, NJ: Humana Press; 2013. p. 109-20.

54. Štefanić S, Shaikenov BS, Deplazes P, Dinkel A, Torgerson PR, Mathis A. Polymerase chain reaction for detection of patent infections of Echinococcus granulosus ("sheep strain") in naturally infected dogs. Parasitol Res. 2004;92(4):347-51.

55. Isaksson M, Hagstrom A, Armua-Fernandez MT, Wahlstrom H, Agren EO, Miller A, et al. A semi-automated magnetic capture probe based DNA extraction and real-time PCR method applied in the Swedish surveillance of Echinococcus multilocularis in red fox (Vulpes vulpes) faecal samples. Parasit Vectors. 2014;7:583. This is the most sensitive PCR assay published for the detection of $\boldsymbol{E}$. multilocularis in faeces.

56. Dinkel A, Kern S, Brinker A, Oehme R, Vaniscotte A, Giraudoux P, et al. A real-time multiplex-nested PCR system for coprological diagnosis of Echinococcus multilocularis and host species. Parasitol Res. 2011;109(2):493-8.

57. Chile N, Clark T, Arana Y, Ortega YR, Palma S, Mejia A, et al In vitro study of Taenia solium postoncospheral form. PLoS Negl Trop Dis. 2016;10(2):e0004396.

58. Jabbar A, Crawford S, Młocicki D, Świderski ZP, Conn DB, Jones MK, et al. Ultrastructural reconstruction of Taenia ovis oncospheres from serial sections. Int J Parasitol. 2010;40(12):1419-31.

59. Swiderski Z. Echinococcus granulosus: hook-muscle systems and cellular organisation of infective oncospheres. Int J Parasitol. 1983;13(3):289-99.

60. Federer K, Armua-Fernandez MT, Gori F, Hoby S, Wenker C, Deplazes P. Detection of taeniid (Taenia spp., Echinococcus spp.) eggs contaminating vegetables and fruits sold in European markets and the risk for metacestode infections in captive primates. Int J Parasitol Parasites Wildl. 2016;5(3):249-53.

61. Poglayen G, Gori F, Morandi B, Galuppi R, Fabbri E, Caniglia R, et al. Italian wolves (Canis lupus italicus Altobello, 1921) and molecular detection of taeniids in the Foreste Casentinesi National Park, Northern Italian Apennines. Int J Parasitol Parasites Wildl. 2017;6(1):1-7.

62. Dyachenko V, Pantchev N, Gawlowska S, Vrhovec MG, Bauer C Echinococcus multilocularis infections in domestic dogs and cats from Germany and other European countries. Vet Parasitol. 2008;157(3):244-53.

63. Alishani M, Sherifi K, Rexhepi A, Hamidi A, Armua-Fernandez MT, Grimm F, et al. The impact of socio-cultural factors on transmission of Taenia spp. and Echinococcus granulosus in Kosovo. Parasitology. 2017;144(13):1736-42.

64. Al-Sabi MN, Kapel CM, Deplazes P, Mathis A. Comparative copro-diagnosis of Echinococcus multilocularis in experimentally infected foxes. Parasitol Res. 2007;101(3):731-6.

65. Dinkel A, von Nickisch-Rosenegk M, Bilger B, Merli M, Lucius R, Romig T. Detection of Echinococcus multilocularis in the definitive host: coprodiagnosis by PCR as an alternative to necropsy. J Clin Microbiol. 1998;36(7):1871-6.

66. Knapp J, Millon L, Mouzon L, Umhang G, Raoul F, Ali ZS, et al. Real time PCR to detect the environmental faecal contamination by Echinococcus multilocularis from red fox stools. Vet Parasitol. 2014;201(1):40-7.

67. Maksimov P, Schares G, Press S, Fröhlich A, Basso W, Herzig M, et al. Comparison of different commercial DNA extraction kits and PCR protocols for the detection of Echinococcus multilocularis eggs in faecal samples from foxes. Vet Parasitol. 2017;237(Supplement C):83-93.

68. Knapp J, Umhang G, Poulle M-L, Millon L. Development of a real-time PCR for a sensitive one-step copro-diagnosis allowing both the identification of carnivore feces and the detection of Toxocara spp. and Echinococcus multilocularis. Appl Environ Microbiol. 2016;82:2950-8.

69. Raoul F, Deplazes P, Nonaka N, Piarroux R, Vuitton DA, Giraudoux P. Assessment of the epidemiological status of Echinococcus multilocularis in foxes in France using ELISA coprotests on fox faeces collected in the field. Int J Parasitol. 2001;31(14):1579-88. 
70. Ziadinov I, Mathis A, Trachsel D, Rysmukhambetova A, Abdyjaparov TA, Kuttubaev OT, et al. Canine echinococcosis in Kyrgyzstan: using prevalence data adjusted for measurement error to develop transmission dynamics models. Int J Parasitol. 2008;38(10):1179-90.

71. Guerra D, Hegglin D, Bacciarini L, Schnyder M, Deplazes P. Stability of the southern European border of Echinococcus multilocularis in the Alps: evidence that Microtus arvalis is a limiting factor. Parasitology. 2014;141(12):1593-602.

72. Thapa NK, Armua-Fernandez MT, Kinzang D, Gurung RB, Wangdi P, Deplazes P. Detection of Echinococcus granulosus and Echinococcus ortleppi in Bhutan. Parasitol Int. 2017;66(2):139-41.

73. Scandrett WB, Gajadhar AA. Recovery of putative taeniid eggs from silt in water associated with an outbreak of bovine cysticercosis. Can Vet J. 2004;45(9):758-60.

74. Verbyla ME, Oakley SM, Lizima LA, Zhang J, Iriarte M, Tejada-Martinez AE, et al. Taenia eggs in a stabilization pond system with poor hydraulics: concern for human cysticercosis? Water Sci Technol. 2013;68(12):2698-703.

75. Diaz F, Garcia HH, Gilman RH, Gonzales AE, Castro M, Tsang VCW, et al. Epidemiology of taeniasis and cysticercosis in a Peruvian village. Am J Epidemiol. 1992;135(8):875-82.

76. Sarti-Gutierrez EJ, Schantz PM, Lara-Aguilera R, Gomez Dandoy H, Flisser A. Taenia solium taeniasis and cysticercosis in a Mexican village. Trop Med Parasitol. 1988;39(3):194-8.

77. Shaikenov BS, Rysmukhambetova AT, Massenov B, Deplazes P, Mathis A, Torgerson PR. Short report: the use of a polymerase chain reaction to detect Echinococcus granulosus (G1 strain) eggs is soil samples. Am J Trop Med Hyg. 2004;71(4):441-3.

78. Szostakowska B, Lass A, Kostyra K, Pietkiewicz H, Myjak P. First finding of Echinococcus multilocularis DNA in soil: preliminary survey in Varmia-Masuria Province, Northeast Poland. Vet Parasitol. 2014;203(1-2):73-9.

79. Rostami A, Ebrahimi M, Mehravar S, Fallah Omrani V, Fallahi S, Behniafar $\mathrm{H}$. Contamination of commonly consumed raw vegetables with soil transmitted helminth eggs in Mazandaran province, northern Iran. Int J Food Microbiol. 2016;225:54-8.

80. Fallah AA, Pirali-Kheirabadi K, Shirvani F, Saei-Dehkordi SS Prevalence of parasitic contamination in vegetables used for raw consumption in Shahrekord, Iran: influence of season and washing procedure. Food Control. 2012;25(2):617-20.

81. Fallah AA, Makhtumi Y, Pirali-Kheirabadi K. Seasonal study of parasitic contamination in fresh salad vegetables marketed in Shahrekord, Iran. Food Control. 2016;60:538-42.

82. Shahnazi M, Jafari-Sabet M. Prevalence of parasitic contamination of raw vegetables in villages of Qazvin Province, Iran. Foodborne Pathog Dis. 2010;7(9):1025-30.

83. Ismail Y. Prevalence of parasitic contamination in salad vegetables collected from supermarkets and street vendors in Amman and Baqa'a —Jordan. Pol J Microbiol. 2016;65(2):201-7.

84. Abougrain AK, Nahaisi MH, Madi NS, Saied MM, Ghenghesh KS. Parasitological contamination in salad vegetables in TripoliLibya. Food Control. 2010;21(5):760-2.

85. Adenusi AA, Abimbola WA, Adewoga TOS. Human intestinal helminth contamination in pre-washed, fresh vegetables for sale in major markets in Ogun State, southwest Nigeria. Food Control. 2015;50:843-9.

86. Adamu NB, Adamu JY, Mohammed D. Prevalence of helminth parasites found on vegetables sold in Maiduguri, northeastern Nigeria. Food Control. 2012;25(1):23-6.

87. Maikai BV, Elisha IA, Baba-Onoja EBT. Contamination of vegetables sold in markets with helminth eggs in Zaria metropolis, Kaduna State, Nigeria. Food Control. 2012;28(2):345-8.
88. Ogbolu DO, Alli OA, Ogunleye VF, Olusoga-Ogbolu FF, Olaosun I. The presence of intestinal parasites in selected vegetables from open markets in south western Nigeria. Afr J Med Med Sci. 2009;38(4):319-24.

89. Kozan E, Gonenc B, Sarimehmetoglu O, Aycicek H. Prevalence of helminth eggs on raw vegetables used for salads. Food Control. 2005;16(3):239-42.

90. Adanir R, Tasci F. Prevalence of helminth eggs in raw vegetables consumed in Burdur, Turkey. Food Control. 2013;31(2):482-4.

91. Lass A, Szostakowska B, Myjak P, Korzeniewski K. The first detection of Echinococcus multilocularis DNA in environmental fruit, vegetable, and mushroom samples using nested PCR. Parasitol Res. 2015;114(11):4023-9.

92. Robertson LJ, Troell K, Woolsey ID, Kapel CMO. Fresh fruit, vegetables, and mushrooms as transmission vehicles for Echinococcus multilocularis in Europe: inferences and concerns from sample analysis data from Poland. Parasitol Res. 2016;115(6):2485-8.

93. Sardella NH, Fugassa MH. Paleoparasitological analysis of rodent coprolites in holocenic samples from Patagonia, Argentina. J Parasitol. 2009;95(3):646-51.

94. Paknezhad N, Mazdarani FH, Hessari M, Mobedi I, Najafi F, Bizhani N, et al. Retrieving ascarid and taeniid eggs from the biological remains of a Neolithic dog from the late 9th millennium BC in Western Iran. Mem Inst Oswaldo Cruz. 2017;112(9):593-5.

95. Gemmell MA. Immunological responses of the mammalian host against tape-worm infections: IV. Species specificity of hexacanth embryos in protecting sheep against Echinococcus granulosus. Immunology. 1966;11(4):325-35.

96. Colli $\mathrm{CW}$, Williams JF. Influence of temperature on the infectivity of eggs of Echinococcus granulosus in laboratory rodents. J Parasitol. 1972;58(3):422-6.

97. Minozzo JC, Gusso RLF, EAd C, Lago O, Soccol VT. Experimental bovine infection with Taenia saginata eggs: recovery rates and cysticerci location. Braz Arch Biol Technol. 2002;45:451-5.

98. Gonzalez AE, Gauci CG, Baarber D, Gilman RH, Tsang VCW, Garcia HH, et al. Vaccination of pigs to control human neurocyticercosis. Am J Trop Med Hyg. 2005;72(6):837-9.

99. Flisser A, Gauci CG, Zoli A, Martinez-Ocaña J, Garza-Rodriguez A, Dominguez-Alpizar JL, et al. Induction of protection against porcine cysticercosis by vaccination with recombinant oncosphere antigens. Infect Immun. 2004;72(9):5292-7.

100. Lightowlers MW, Mitchell GF, Bowtell DDL, Anders RF, Rickard MD. Immunization against Taenia taeniaeformis in mice: studies on the characterization of antigens from oncospheres. Int J Parasitol. 1984;14(3):321-33. This paper used the sodium hypochlorite method to hatch mature taeniid eggs showing an excellent recovery of oncospheres

101. Deplazes P, Grimm F, Sydler T, Tanner I, Kapel CMO. Experimental alveolar echinococcosis in pigs, lesion development and serological follow up. Vet Parasitol. 2005;130(3):213-22.

102. Deplazes P, Eckert J. Mass collection and storage of Taenia hydatigena eggs and isolation of viable oncospheres. Schweiz Arch Tierheilkd. 1988;130(6):307-20.

103. Moazeni M, Rakhshandehroo E. In vitro viability test for the eggs of Echinococcus granulosus: a rapid method. Parasitol Res. 2012;110(2):925-30.

104. Sánchez Thevenet P, Alvarez HM, Basualdo JA. Survival, physical and physiological changes of Taenia hydatigena eggs under different conditions of water stress. Exp Parasitol. 2017;177:4756. 